\title{
FERMENTED BLOOD MEAL USE FOR TIGER GROUPER, Epinephelus fuscoguttatus GROW OUT DIET
}

\author{
Usman*), Kamaruddin*), Neltje N. Palinggi*), Rachmansyah*), and Taufik Ahmad ${ }^{* *}$
}

\begin{abstract}
The experiment aimed to evaluate the optimal level of fermented blood meal used in grow- out diets for tiger grouper, as an alternative protein source to fish meal. Juvenile tiger grouper, initial weight $31.1 \pm 2.1 \mathrm{~g}$, were stocked into $1 \times 1 \times 2 \mathrm{~m}^{3}$ floating net cages at 20 fish $^{\text {cage }^{-1}}$. The treatment applied was isoprotein and isocaloric diets formulated to contain fermented blood meal (FBM) of $0 \% 7.5 \% 15.0 \% 22.5 \%$ and $30.0 \%$ replacement of fish meal protein. The diets were fed to the fish twice a day to satiation for 20 weeks. Based on the Tukey test, the fish fed $0 \%-15.0 \%$ FBM demonstrated similar performance $(P>0.05)$ to those fed the control diet $\left(\mathrm{FBM}_{0}\right)$ in terms of specific growth rate, weight gain, and feed and protein efficiency. Specific growth rate, weight gain, feed efficiency and protein efficiency of the fish fed $22.5 \%$ $30.5 \%$ FBM were significantly lower $(P<0.05)$ than those of the fish fed control diet $\left(\mathrm{FBM}_{0}\right)$. However, there was a significant culvilinier decliner in overall fish performance with increasing inclusion of FPM and most notable for weight gain, feed efficiency and feed consumption. Based on regression analysis, the asymptote where fish growth deteriorates as a function of FBM inclusion was determined to be $8.9 \%$ Tiger grouper diets incorporating up to $9 \%$ FBM as fish meal replacement had no adverse affects on fish growth and survival.
\end{abstract}

\section{KEYWORDS: fermented blood meal, tiger grouper grow- out}

\section{INTRODUCTION}

Tiger grouper (Epinephelus fuscoguttatus) is a piscivorous fish having a short digestive tract, around $0.20-0.25$ body length (Smith, 1980a), low enzyme activity for a high carbohydrate diet (Lupatsch et al., 1997) and like other grouper species, is expected to preferentially utilise dietary protein as an energy source (Williams et al., 2004; Tuan \& Williams, 2007). Several studies (Smith, 1980b; Laining et al., 2003a; Kabangnga et al., 2004) have demonstrated that tiger grouper grow well when fed $45 \%-55 \%$ protein and $<15 \%$ lipid. However, to formulate a diet with $>45 \%$ protein typically requires fish meal to be included at a rate of at least $50 \%$ At a feed conversion ratio of around 2.0:1 and a conversion rate of trash fish into fish meal of 4.0:1, every kilogram of tiger grouper produced requires the equivalence of at least $4 \mathrm{~kg}$ of 'trash' fish. The term 'trash' fish is inaccurate in Indonesia because such fish are utilised for human consumption, either directly or for the manufacture of fish sauce. Because of this competition for fish protein, substitution of fish meal with terrestrial sources of protein is a priority for the aquafeed industry.

Blood meal is one of the potential sources of protein that could be used to replace fish meal in fish diets. The protein content of blood meal is high, around $72 \%-97 \%$ (Hertrampf \& Piedad- Pascual, 2000; Laining et al., 2003b). However, processing methods affect the quality of blood meal, which in turn, affects the reponse of the fish. With humpback grouper Cromileptes altivelis, Laining et al. (2003b)

*) Research Institute for Coastal Aquaculture, Maros, Indonesia

**) Research Institute for Fresh Water Aquaculture, Bogor, Indonesia 
reported that the dry matter and crude protein digestibility of oven-dried blood meal was $48 \%$ and $55 \%$ respectively. However, organic acid fermentation of the dried blood meal improved digestibility to $62 \%-68 \%$ and $84 \%-88 \%$, respectively.

Substitution of fish meal with blood meal products has given conflicting results. With Chinook salmon (Oncorhynchus tschawynchus) (Hajen et al., 1993) found that substituting including more than $5 \%$ spray dried blood meal as a substitute for fish meal resulted in retarded fish growth. In contrast, $25 \%$ replacement of fish meal protein with blood and meat meal had no adverse effect on salmon growth but increasing the replacement to $75 \%$ resulted in a $19 \%$ reduction in growth and a $25 \%$ worsening of feed conversion (Gropp et al., 1976 in Hertrampf \& Piedad-Pascual, 2000). The objective of this study was to evaluate the optimum rate at which fermented blood meal could substitute for fish meal in the diet of tiger grouper.

\section{MATERIAL AND METHODS}

\section{Test Diets}

The reference protein source used in the study was Peruvian fish meal (PFM). Except for the control diet $\left(\mathrm{FBM}_{0}\right)$ which contained only PFM as the source of protein, other test diets contain fermented blood meal (FBM) at inclusion rates of $7.5 \%\left(\mathrm{FBM}_{75}\right), 15.0 \%\left(\mathrm{FBM}_{15}\right), 22.5 \%$ $\left(\mathrm{FBM}_{22.5}\right)$, and $30.0 \%\left(\mathrm{FBM}_{30}\right)$ and substituting for an equivalent amount of PFM protein. Fresh cattle blood from an abattoir in Maros Regency, South Sulawesi was collected in a plastic bucket and homogeneously mixed with 1:1 propionic and formic acid mixture at 3\% of blood total weight (Laining et al., 2003b). Fermentation was carried out for 5 days with daily agitation. At the conclusion of fermentation, the acidity of the mixture was $\mathrm{pH} 3-4$ and this was neutralised with $1.6 \%$ $\mathrm{Ca}(\mathrm{OH})_{2}$ (Stone et al., 1989) to obtain a product with a $\mathrm{pH}$ of $6.0-6.5$. The fermented blood was dried and ground to a fine powder. The blood meal product contained $82.7 \%$ crude protein (CP), 0.01\%total lipid (TL), 2.7\%crude fiber (CF), $4.8 \%$ ash, and $9.7 \%$ nitrogen free extract (NFE). All raw ingredients were stored in a refrigerator prior to their use for feed formulation. The formulation and proximate analysis of the test diets are presented in Table 1. Chromium oxide at $1 \%$ was added to the diet at the expense of wheat flour when used for determining diet digestibility.

Dryingredients for daily- made moist pellet were homogenously mixed in a mixer and than combined with oil. Trash fish was finely grinded and homogenously mixed with flour and oil. The mixture of dry ingredients and trash fish then was blended into dough. Pellets were made by cold extruding the dought through a meat mincer with a die opening of $7-12 \mathrm{~mm}$. The moisture content of the pellets averaged $40 \%$ Prior to be fed, the pellet was kept in a cool box filled with ice.

\section{Experimental Procedures}

Hatchery- reared juvenile tiger grouper from a single cohort were stocked into floating net cages for several weeks' acclimatisation during which time they were fed the control formulation moist pellet $\left(\mathrm{FBM}_{0}\right)$. Three hundred and ten healthy fish of an uniform size were selected for the experiment. Average initial weight (mean \pm SD) of the fish was $31.1 \pm 2.1 \mathrm{~g}$. Three hundred fish were stocked into 15 units of $1 \times 1 \times 2 \mathrm{~m}$ floating net cages at a density of 20 fish cage $^{-1}$. The remaining 10 fish were sacrificed to determine initial whole body chemical composition. The experimental units were arranged in a completely randomized design with 3 replicates of each diet treatment. The fish were carefully fed twice each day to satiation for 140 days and were sampled every 4 weeks for weight measurement.

Digestitibility of the test diet was determined indirectly by reference to the digestibility marker chromium oxide $\left(\mathrm{Cr}_{2} \mathrm{O}_{3}\right)$ as described by Takeuchi (1988). Prior to faeces collection, experimental fish were fed test diets containing chromium oxide to satiation for 5 days. Several hours after feeding, experimental fish were carefully moved into conical bottom fibreglass tanks fitted with a faecal collection trap similar to that as described by Allan et al. (1999). While in the digestibility tanks, fish were provided with aeration and circulating sea water. Faeces were collected by procedures similar to those of Allan et al. (1999).

\section{Growth and Feed Consumption}

The calculated growth variables were relative weight gain (\%) in 140 days and specific growth rate (SGR). The calculation of SGR was based on Schulz et al. (2005) equation as follows: 
Table 1. Formulation (\%), proximate analysis (\%dry matter) and energy content (MJ/ kg dry matter) of test diets containing fermented blood meal (FBM)

\begin{tabular}{|c|c|c|c|c|c|}
\hline \multirow{2}{*}{ Ingredient } & \multicolumn{5}{|c|}{ Test diets } \\
\hline & FBM $_{0}$ & $\mathrm{FBM}_{7.5}$ & $\mathrm{FBM}_{15}$ & $\mathrm{FBM}_{22.5}$ & $\mathrm{FBM}_{30}$ \\
\hline Trash fish ${ }^{1}$ & 18.5 & 18.5 & 18.5 & 18.5 & 18.5 \\
\hline Fish meal & 48.5 & 38.5 & 28.5 & 18.5 & 8.5 \\
\hline Fermented blood meal & 0 & 7.5 & 15 & 22.5 & 30 \\
\hline Shrimp head meal & 9 & 9 & 9 & 9 & 9 \\
\hline Rice bran & 4 & 4 & 4 & 4 & 4 \\
\hline Wheat flour & 13 & 14.5 & 16 & 17.5 & 19 \\
\hline Fish oil & 1 & 2 & 3 & 4 & 5 \\
\hline Soybean oil & 2 & 2 & 2 & 2 & 2 \\
\hline Vitamin premix ${ }^{2}$ & 3 & 3 & 3 & 3 & 3 \\
\hline Mineral premix ${ }^{3}$ & 1 & 1 & 1 & 1 & 1 \\
\hline \multicolumn{6}{|l|}{ Proximate analysis } \\
\hline Crude protein & 45.8 & 46.1 & 46.5 & 46.6 & 47.1 \\
\hline Total lipid & 10.4 & 10.5 & 10.8 & 10.9 & 11.1 \\
\hline Fibre & 2.4 & 2.6 & 3.0 & 2.5 & 2.4 \\
\hline Ash & 16.9 & 15.5 & 14.8 & 13.7 & 13.2 \\
\hline Energy ${ }^{4}$ & 19.1 & 19.4 & 19.5 & 19.7 & 20.0 \\
\hline
\end{tabular}

$174 \mathrm{~g}$ trash fish, equivalent to $18.5 \mathrm{~g}$ of dried fish meal was used

2 Vitamin premix provided ( $\mathrm{mg} \mathrm{kg}^{-1}$ diet): Thiamin- $\mathrm{HCl}, 59.2$; riboflavin, 59.2; Ca- panthothenate, 118.5; niacin, 23.7; pyridoxine- $\mathrm{HCl}$, 47.4; biotin, 7.1; folic acid, 17.8; inositol, 2370; p- aminobenzoic, 59.2; astaxanthin, 177.8; menadione, 47.4; calciferol, 22.5; $\mu$-tocopherol, 237; ascorbic acid, 1777.5; cyanocobalamin, 1.2; choline-HCL, 10971

3 Mineral premix provided (mg kg-1 diet): $\mathrm{KH}_{2} \mathrm{PO}_{4}, 2000 ; \mathrm{CaCO}_{3}, 2500 ; \mathrm{NaH}_{2} \mathrm{PO}_{4}, 3150$; $\mathrm{FeCl}_{3} .2 \mathrm{H}_{2} \mathrm{O}, 1660 ; \mathrm{ZnSO}_{4}, 100 ; \mathrm{MnSO}_{4}, 67.5 ; \mathrm{MgSO}_{4}, 500 ; \mathrm{CuSO}_{4}, 20 ; \mathrm{KI}, 1.5 ; \mathrm{CoSO}_{4} .7 \mathrm{H}_{2} \mathrm{O}, 1.0$

4 Calculated from the determined protein, lipid and NFE of the diet using gross energy convertion coefficients of 23.6, 39.5, and $17.2 \mathrm{MJ} \mathrm{kg}^{-1}$, respectively (National Research Council, 1993).

$$
F E=\frac{\text { fish weight gain ( } g \text { wet weight) }}{\text { feed consumption ( } g \text { dry weight) }}
$$

$$
\operatorname{SGR}\left(\% \text { day }^{1}\right)=100 \times\left(\ln \mathrm{W}_{\mathrm{e}}-\ln \mathrm{W}_{\mathrm{s}}\right) / \mathrm{d}
$$

Where: $\quad$ We $=$ fish final weight $(\mathrm{g})$, Ws $=$ fish initial weight $(\mathrm{g})$, and $\mathrm{d}=$ rearing period (days)

Feed efficiency (FE) was calculated using the equation of Takeuchi (1988) as follows:

Protein efficiency ratio (PER) was calculated based on the following equations of Takeuchi (1988) and Hardy (1989):

$$
\mathrm{PER}=\frac{\text { fish weight gain ( } \mathrm{g} \text { wet weight) }}{\text { total protein consumed ( } \mathrm{g} \text { dry weight) }}
$$

The calculation of DM, CP, TL, and energy (E) apparent digestibility (AD) was based on Watanabe (1988) and Hardy (1989) equations as follows:

$$
A D(\%)=100 *\left[1 A_{M_{F} * A_{D}}^{M_{D} * A_{F}} B\right]
$$

Where: $\mathrm{M}_{\mathrm{D}}$ and $\mathrm{M}_{\mathrm{F}}$ are $\mathrm{Cr}_{2} \mathrm{O}_{3}$ dry weight indicator concentrations in diet and faeces, respectively. $A_{D}$ and $A_{F}$ are concentrations of dry weight nutrient in diet and faeces, respectively.

\section{Chemical and Statistical Analysis}

Initial fish whole body analysis was determined for a pooled sample of 10 fish; a representative sample of 5 fish from each net 
cage was used to determine the final whole body composition of the fish. The fish samples were minced, freeze-dried and pulverized using a mortar and pestle. The dry sample was blended to get a homogenous fine product. Representative samples of feed ingredients, fish, diet, and faeces were analysed based on AOAC International (1999) methods. DM was determined by drying in an oven at $105^{\circ} \mathrm{C}$ for 16 hours, ash by ignition in a muffle furnace at $550^{\circ} \mathrm{C}$ for 24 hours and crude protein was analysed using a micro- Kjeldahl procedure with distillation into $4 \%$ boric acid and titration with sulphuric acid using methyl red indicator for end point determination. Total lipid was gravimetrically determined with chloroform: methanol extraction (Bligh \& Dyer, 1959). Analysis of chromium concentration in diet and faeces samples was analysed based on Takeuchi's (1988) procedures. For amino acid analysis, samples were hydrolysed using 6 molar $\mathrm{HCL}$ at $110^{\circ} \mathrm{C}$ for 22 hours and amino acid content quantified using a Hitachi 835 high speed amino acid analyzer.

Weight gain, daily growth rate, feed efficiency, feed consumption, protein efficiency ratio, fish survival rate, and whole body fish composition data were analysed using ANOVA and regression analytical procedures. Tukey test (Steel \& Torrie, 1995) was used to detect significant ANOVA treatment effect. Apparent digestibility was determined for only a single replicate for each treatment and thus was not statistically analysed.

\section{RESULTS AND DISCUSSION}

Fermented blood meal contained relatively less methionine, cysteine and isoleucine than PFM or whole body tiger grouper protein (Table 2 ). However, acid hydrolysis is known to partially destroy sulphur amino acids, resulting in low estimates for methionine and cysteine; tryptophan is also destroyed by acid hydrolysis. While the analysed value for methionine and cysteine detailed in Table 2 are under estimates, it is clear that blood meal is low in sulphur amino acids and isoleucine. Methionine and isoleucine are essential amino acids that are required for fish growth. Asgard \& Austreng (1986) reported that blood meal contains less methionine and isoleucine but more leucine than fish meal. Blood meal therefore is not a complete source of dietary protein for fish but could be a useful supplementary source of protein if combined with feed ingredients that contain high amounts of methionine and isoleucine. The fish fed moist pellet containing $22.5 \%$ or more of fermented blood meal grew significantly slower $(P<0.05)$ than fish fed the control diet. Fish fed the $30 \%$ fermented blood meal diet grew $47 \%$ slower than fish fed the control diet.

Table 3 shows that specific growth rate, weight gain, feed efficiency and protein efficiency ratio of fish fed diets containing up to $15 \%$ FBM diets were not significantly $(P>0.5)$ different and all were higher than those fed $22.5 \% 30.0 \%$ FBM diets. However, there was a

Table 2. Essential amino acid composition of fish meal, fermented blood meal, and whole body of tiger grouper protein (\%dry matter)

\begin{tabular}{lccc}
\hline \multicolumn{1}{c}{ Amino acid } & PFM & $\begin{array}{c}\text { Fermented } \\
\text { blood meal }\end{array}$ & $\begin{array}{c}\text { Tiger } \\
\text { grouper }\end{array}$ \\
\hline Arginine & 4.20 & 4.05 & 3.63 \\
Histidine & 2.40 & 5.78 & 1.02 \\
Isoleucine & 2.63 & 0.70 & 2.42 \\
Leucine & 5.43 & 10.91 & 3.99 \\
Lysine & 5.74 & 7.36 & 3.77 \\
Methionine +Cystine & 2.13 & 0.29 & 0.47 \\
Phenylalanine & 3.18 & 6.34 & 2.04 \\
Threonine & 3.33 & 4.50 & 2.47 \\
Valine & 3.10 & 6.40 & 2.64 \\
Tryptophan & 1.68 & $\mathrm{nd}$ & $\mathrm{nd}$ \\
\hline
\end{tabular}

Note: $\mathrm{nd}=$ not detectable 
significant culvilinear decline in overall fish performance with increasing inclusion of FPM and most notable for weight gain, feed efficiency and feed consumption (Table 3, Figure 1). Based on regression analysis, the reduction in fish growth is modelled by the equation: $\mathrm{FW}=222.4-1.319 \mathrm{FBM}-0.07369$ $\mathrm{FBM}^{2}$. From this equation, the asymptote where fish growth deteriorates as a function of FBM inclusion was determined to be $8.9 \%$

Feed consumption was lower for all diets contained FBM. Unpalatability of the diets containing FBM is the most likely reason for the reduced fish growth associated with increasing dietary inclusion of FBM. Asgard \& Austreng (1986) reported a similar result with salmonids fed a diet containing 33\%fermented blood jelly, equivalent to $20 \%$ moist pellet protein.

In our experiment, there was no difference in survival rate between the different treatments $(P>0.05)$, indicating that up to $30 \%$ fermented blood meal in diet did not affect fish health. Similarly, Asgard \& Austreng (1986) found that the survival rate of salmon fed a diet with $33 \%$ fermented blood jelly was not different from that of fish fed control diet enriched with fish waste as a source of protein.

According to Hertrampf \& Piedad- Pascual (2000), blood meal handling prior to its inclusion in feed formulation affects its digestibility. A similar finding was reported by

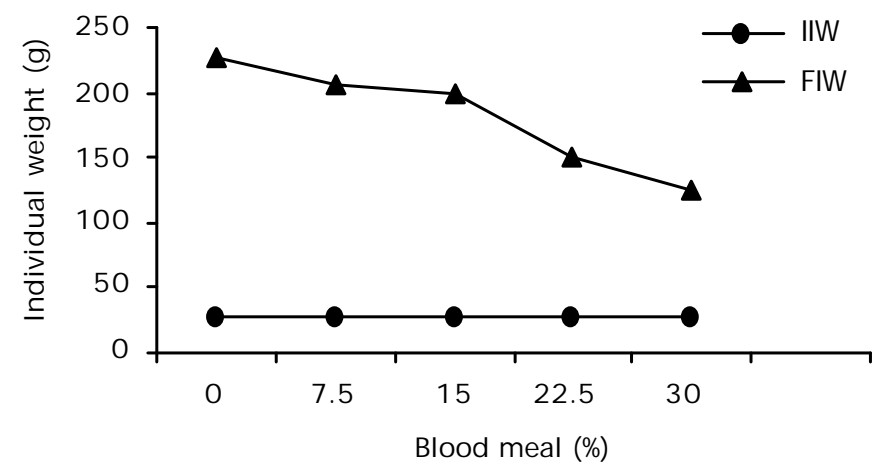

Figure 1. Initial (IIW) and final (FIW) individual weight of tiger grouper fed diets containing different levels of fishmeal substitution with fermented blood meal

Table 3. Growth performance and feed utilization of tiger grouper fed diets containing different level of fermented blood meal (FBM)

\begin{tabular}{|c|c|c|c|c|c|}
\hline \multirow{2}{*}{ Variable } & \multicolumn{5}{|c|}{ Test diets* } \\
\hline & FBM $_{0}$ & FBM $_{7.5}$ & FBM $_{15}$ & $\mathrm{FBM}_{22.5}$ & $\mathrm{FBM}_{30}$ \\
\hline Initial weight (g) & 31.1 & 31.2 & 31.3 & 31.2 & 31.1 \\
\hline Final weight (g) & 224.0 & 201.4 & 196.7 & 148 & 118.5 \\
\hline Specific growth rate $\left(\%\right.$ day $\left.^{-1}\right)$ & $1.41^{\mathrm{a}}$ & $1.33^{\mathrm{a}}$ & $1.31^{\mathrm{a}}$ & $1.11^{\mathrm{b}}$ & $0.96^{b}$ \\
\hline Weight regression slope & $38.6^{a}$ & $33.5^{a}$ & $32.7^{a}$ & $23.3^{b}$ & $17.1^{\mathrm{b}}$ \\
\hline Weight gain $(\%$ & $621.6^{a}$ & $545.2^{a}$ & $529.1^{a}$ & $373.6^{b}$ & $280.8^{b}$ \\
\hline Feed efficiency & $0.71^{\mathrm{a}}$ & $0.68^{a}$ & $0.68^{a}$ & $0.49^{\mathrm{b}}$ & $0.39^{b}$ \\
\hline Feed consumption (g fish ${ }^{-1}$ ) & $265.0^{a}$ & $247.3^{b}$ & $241.4^{\mathrm{b}}$ & $234.4^{\mathrm{bc}}$ & $222.4^{\mathrm{c}}$ \\
\hline Protein efficiency ratio & $1.54^{\mathrm{a}}$ & $1.47^{\mathrm{a}}$ & $1.48^{\mathrm{a}}$ & $1.04^{\mathrm{b}}$ & $0.83^{c}$ \\
\hline Survival rate $(\%)$ & $91.7^{\mathrm{a}}$ & $93.3^{a}$ & $95.0^{a}$ & $88.3^{a}$ & $95.0^{\mathrm{a}}$ \\
\hline
\end{tabular}

* Means in the same row followed by similar superscript are not significantly different $(\mathrm{P}>0.05)$ 
Laining et al. (2003) who demonstrated that DM digestibility of blood meal was only $48 \%$ while that of the protein was only slightly higher at 55\% However, blood meal fermented with formic and propionic acid had higher digestibilities of $62 \% 68 \%$ for DM and $84 \% 88 \%$ for CP. The digestibility of feed containing fermented blood meal in this experiment was relatively high, $71.4 \%-76.5 \%$ for dry matter, $84.4 \% 88.1 \%$ for protein, and $93.3 \% 94.7 \%$ for lipid (Table 4). However, the digestibility of the feed appears to decrease with increasing blood meal content but the digestibility of lipid remaining high for all diets. Digestibility of salmon feed containing $24.5 \%$ fermented blood jelly was not different from the feed containing $54 \%$ fish waste; $71 \%$ for dry matter, $87 \%$ for protein, and $86 \%$ for lipid (Asgard \& Austreng, 1986).

The whole body composition of fish fed at the end of the experiment was similar for all diet treatments (Table 5). Protein content ranged from $57.5 \%$ to $58.1 \%$ and lipid from $21.3 \%$ to $21.7 \%$ The similarity of the chemical composition of the fish across all treatments indicates that including up to $30 \%$ of fermented blood meal in the diet, while depressing fish growth rate, had little effect on the nutrient composition of the fish.

\section{CONCLUSION}

Fermented blood meal added to the diet at less than $9 \%$ does not adversely affect tiger grouper growth. Including more than $9 \%$ fermented blood meal as a replacement for fish meal protein is likely to depress fish performance, most likely due to the un palability of the diet and its effect of reducing feed consumption. Depending on relative ingredients costs, it may be economic to include more than $9 \%$ fermented blood meal in the diet, with the lower fish productivity being compensated for by the lower feed cost.

\section{ACKNOWLEDGMENT}

The help of Makmur, Reni Yulianingsih, Rosni, Tamsil, Yohanes Tekken, and Ramadhan to smoothly carry out the experiment is highly appreciated. The experiment was financed by GOI through APBN Fiscal Year 2006 as a counter budget for the Collaborative Project of ACIAR NO. FIS/ 2002/ 077.

Tabel 4. Apparent digestibility coefficients of tiger grouper diets containing different levels of fermented blood meal

\begin{tabular}{lccc}
\hline \multirow{2}{*}{$\begin{array}{c}\text { Test } \\
\text { diet }\end{array}$} & \multicolumn{2}{c}{ Variable of feed digestibility (\%) } \\
\cline { 2 - 4 } & Dry matter & Protein & Lipid \\
\hline $\mathrm{FBM}_{0}$ & 76.5 & 88.1 & 94.5 \\
$\mathrm{FBM}_{7.5}$ & 75.7 & 87.5 & 94.7 \\
$\mathrm{FBM}_{15}$ & 74.5 & 86.8 & 93.7 \\
$\mathrm{FBM}_{22.5}$ & 71.7 & 84.9 & 93.3 \\
$\mathrm{FBM}_{30}$ & 71.4 & 84.4 & 93.9 \\
\hline
\end{tabular}

Table 5. Whole body composition of tiger grouper fed diet containing different levels of fermented blood meal (\%dry weight)

\begin{tabular}{lccccc}
\hline \multirow{4}{*}{ Nutrient } & \multicolumn{5}{c}{ Test diets* $^{*}$} \\
\cline { 2 - 6 } & FBM $_{\mathbf{0}}$ & FBM $_{\mathbf{7 . 5}}$ & FBM $_{\mathbf{1 5}}$ & FBM $_{\mathbf{2 2 . 5}}$ & FBM $_{\mathbf{3 0}}$ \\
\hline Crude protein & $57.5^{\mathrm{a}}$ & $57.7^{\mathrm{a}}$ & $58.1^{\mathrm{a}}$ & $57.6^{\mathrm{a}}$ & $58.1^{\mathrm{a}}$ \\
Total lipid & $21.7^{\mathrm{a}}$ & $21.4^{\mathrm{a}}$ & $21.3^{\mathrm{a}}$ & $21.6^{\mathrm{a}}$ & $21.5^{\mathrm{a}}$ \\
Ash & $16.3^{\mathrm{a}}$ & $16.0^{\mathrm{a}}$ & $15.8^{\mathrm{a}}$ & $17.3^{\mathrm{a}}$ & $15.7^{\mathrm{a}}$ \\
Crude fibre & $2.1^{\mathrm{a}}$ & $2.1^{\mathrm{a}}$ & $2.0^{\mathrm{a}}$ & $2.1^{\mathrm{a}}$ & $2.1^{\mathrm{a}}$ \\
\hline
\end{tabular}

* Means in the same row followed by similar superscript are not significantly different $(P>0.05)$ 


\section{REFERENCES}

AOAC International. 1999. Official Methods of Analysis, $16^{\text {th }}$ edn. Association of Official Analytical Chemists International, Gaithersberg, Maryland, USA. 1,141 pp.

Allan, G.L., S.J. Rowland, S. Parkinson, D.J. Stone, and W. Jantrarotai. 1999. Nutrient digestibility for juvenile silver perch Bidyanus bidyanus: development of methods. Aquaculture. 170: 131-145.

Asgard, T. and E. Austreng. 1986. Blood, ensiled or frozen, as feed for salmonids. Aquaculture. 55: 263-284.

Bligh, E.G. and W.J. Dyer. 1959. A rapid method of total lipid extraction and purification. Canadian Journal of Biochemistry and Physiology. 37: 911-917.

Hajen, W.E., R.M. Beames, D.A. Higgs. and B.S. Dosanjh. 1993b. Digestibility of various feedstuffs by post-juvenile Chinook salmon (Oncorhyncus tshawytscha) in sea water, 2. Measurement of digestibility. Aquaculture. 112(4): 333-348.

Hardy, R.W. 1989. Diet preparation. In Halver, J.E. (ed.). Fish Nutrition. Second Edition. Academic Press, Inc. San Diego. p. 476549.

Hertrampf, J.W. and P. Piedad- Pascual. 2000. Handbook on ingredient for aquaculture feeds. Kluwer Academic Publishers. 573 $\mathrm{pp}$.

Kabangnga, N., Burhanuddin, Usman, S. Lante, dan Kamaruddin. 2004. Kebutuhan optimum protein dan energi pakan pembesaran ikan kerapu macan di tambak. Laporan Hasil Penelitian. Balai Riset Perikanan Budidaya Air Payau.

Laining, A., N. Kabangnga, dan Usman. 2003a. Pengaruh protein pakan yang berbeda terhadap koefisien kecernaan nutrien serta performansi biologis kerapu macan, Epinephelus fuscoguttatus, dalam keramba jaring apung. J. Pen. Perik. Indonesia. 9(2): 29-34.

Laining, A., Rachmansyah, T. Ahmad, and K. Williams. 2003b. Apparent digestibility of selected feed ingredient for humpback grouper, Cromileptes altivelis. Aquaculture. 218: 529-538.

Lupatsch, I., G.W. Kissil, D. Skland, and E. Pfeffer. 1997. Apparent digestibility coefficients of feed ingredients and their predictability in compound diets for gilthead seabream, Sparus aurata L. Aquaculture Nutrition. 3: 81-89.

National Research Council (NRC). 1993 Nutrient requirements of fish. National Academy of Science, Washingtong, D.C. $114 \mathrm{pp}$.

Schulz, C., U. Knaus, M. Wirth, and B. Rennert. 2005. Effect of varying dietary fatty acid propile on growth performance, fatty acid, body and tissue composition of juvenile pike perch (Sander lucioperca). Aquaculture Nutrition, 11: 403-413.

Smith, L.S. 1980a. Digestion in teleost fishes. In Fish Feed Technology. ADCP/REP/80/ 11. UNDP, FAO, Rome. www.fao.org/ docrep/X5738E/ X5738e02.htm\#TopOf Page [13- 3- 03]

Smith, L.S. 1980b. Protein and amino acid. In Fish Feed Technology. ADCP/REP/80/11. UNDP, FAO, Rome. www.fao.org/docrep/ X5738E/ X5738e03.htm\#TopOfPage [13- 303]

Steel, R.G.D. dan Torrie. J.H. 1995. Prinsip dan prosedur statistika. Alih bahasa: Bambang Sumantri. Gramedia Pusaka Utama, Jakarta. $748 \mathrm{pp}$

Stone, F.E., R.W. Hardy, K.D. Shearer, and T.M. Scott. 1989. Utilization of fish silage by rainbow trout (Salmo gairdneri). Aquaculture. 76: 109-118.

Takeuchi, T. 1988. Laboratory work- chemical evaluation of dietary nutrient. In Watanabe, $\mathrm{T}$ (ed.). Fish Nutrition and Mariculture. Tokyo: JICA Kanagawa International Fisheries Training Centre. p. 179-233.

Tuan, L.A. and K.C. Williams. 2007. Optimum dietary protein and lipid specifications for juvenile malabar grouper (Epinephelus malabaricus). Aquaculture (in press).

Watanabe, T. 1988. Fish nutrition and mariculture. JICA Textbook The General Aquaculture Course. Department of Aquatic Biosciences, Tokyo University of Fisheries. 233 pp.

Williams, K.C., S. Irvin, and M. Barclay. 2004. Polka dot grouper Cromileptes altivelis fingerlings require high protein and moderate lipid diets for optimal growth and nutrient retention. Aquaculture Nutrition, 10: 125-134. 